\title{
Omega-3-Fatty Acids Hold Therapeutic Potential for the Prevention and Treatment of Diabetic Neuropathy
}

\author{
J. CLAIRE MACIEJEWSKI, MATTHEW P. HARRIS, MEGAN L. SCHALLER, DAVID S. \\ UMBAUGH, KARIN E. SANDOVAL, KENNETH A. WITT, JOSHUA S. WOOTEN, and \\ BRIANNE L. GUILFORD
}

Exercise Physiology Laboratory; Department of Applied Health; Southern Illinois University Edwardsville; Edwardsville, IL

Category: Undergraduate,
Advisor / Mentor: Guilford, Brianne (bguilfo@siue.edu)
ABSTRACT

Diabetic neuropathy is a debilitating complication of diabetes, affecting over $50 \%$ of diabetic patients. Overweight humans display manifestations of diabetic neuropathy before developing overt diabetes and mice fed a high fat diet exhibit signs of neuropathy including mechanical hindpaw hypersensitivity and neuronal inflammation, suggesting fat diet-induced inflammation may play a role in the development of neuropathy. Omega-3 (n-3) fatty acids have antiinflammatory properties and may hold therapeutic potential as a preventative treatment for prediabetic and diabetic patients at risk for neuropathy. PURPOSE: Investigate the impact of diet composition on signs of neuropathy. We hypothesized that a diet rich in $n-3$ fatty acids would attenuate hindpaw hypersensitivity during prolonged feeding of a high fat diet. METHODS: C57BL/6 mice were randomized into four diet groups ( $n=12$ /group) for 32 weeks: $10 \%$ low fat-fish oil (LFFO), $41 \%$ high fat-fish oil (HFFO), $10 \%$ low fat-lard (LFL), or $41 \%$ high fat-lard (HFL). Neuropathy was characterized at baseline and every other week thereafter using the von Frey behavioral test for hindpaw mechanical sensitivity. A glucose tolerance test was performed at end study, and total area under the curve (AUC) was calculated using the trapezoidal method. RESULTS: At end study, body weight was greater in HFL compared to all other groups. Body weight was also greater in HFFO compared to LFFO. Fasting glucose and glucose AUC were higher in HFL compared to LFFO and HFFO. Following the same pattern as body weight, fasting glucose was higher in HFFO compared to LFFO. Although percent paw withdrawal was greater in HFL compared to HFFO and LFFO, there were no significant differences for LF vs. HF for fish oil or lard. CONCLUSION: A HFL diet induced signs of neuropathy including hindpaw hypersensitivity, whereas a fish oil diet was protective against hindpaw hypersensitivity. Moreover, omega-3-fatty acids may hold therapeutic potential for neuropathy prevention in nondiabetic and diabetic patients.

\begin{tabular}{|l|c|c|c|c|}
\hline \multicolumn{1}{|c|}{$\begin{array}{c}\text { End Study Values } \\
(\mathbf{3 2} \text { wks) }\end{array}$} & $\begin{array}{c}\text { Low Fat Fish } \\
\text { Oil (LFFO) }\end{array}$ & $\begin{array}{c}\text { High Fat Fish Oil } \\
(\text { HFFO) }\end{array}$ & $\begin{array}{c}\text { Low Fat Lard } \\
(\text { LFL) }\end{array}$ & $\begin{array}{c}\text { High Fat Lard } \\
(\text { HFL) }\end{array}$ \\
\hline Body weight (g) & $34.3 \pm 0.6$ & $39.5 \pm 1.6^{\mathrm{a}}$ & $37.2 \pm 1.1$ & $44.3 \pm 1.7^{\mathrm{a}, \mathrm{b}, \mathrm{c}}$ \\
\hline Fasting glucose (mg/dl) & $129.1 \pm 5.6$ & $152.0 \pm 7.7^{\mathrm{a}}$ & $148.1 \pm 5.2$ & $158.8 \pm 8.8^{\mathrm{a}}$ \\
\hline $\begin{array}{l}\text { Glucose AUC total } \\
\text { (mg /120 min / dl) }\end{array}$ & $5368.1 \pm 678.9$ & $7282.6 \pm 1144.4$ & $7384.3 \pm 685.4$ & $9149.6 \pm 1013.8^{\mathrm{a}}$ \\
\hline Percent paw withdrawal (\%) & $22.5 \pm 4.5$ & $29.2 \pm 6.4$ & $37.5 \pm 7.2$ & $54.2 \pm 5.7^{\mathrm{a}, \mathrm{b}}$ \\
\hline
\end{tabular}

${ }^{\mathrm{a}} \mathrm{P}<0.05$ vs. LFFO; ${ }^{\mathrm{b}} \mathrm{P}<0.05$ vs. HFFO; and ${ }^{\mathrm{c}} \mathrm{P}<0.05$ vs. LFL

Supported by NIH R21NS090282-01

International Journal of Exercise Science

www.tacsm.org 